\title{
An Investigation on Compressive Strength of Concrete Blended With Groundnut Shell Ash
}

\author{
Abdul Wahab Abro, Zubair Hussain Shaikh, Ali Aizaz Dayo \\ M.E student, Department of Civil Engineering, Mehran University of Engineering \& \\ Technology Jamshoro, Sindh, Pakistan \\ ablwab82@gmail.com \\ Aneel Kumar \\ Professor, Department of Civil Engineering, Mehran University of Engineering \& Technology \\ Jamshoro, Sindh, Pakistan. \\ Manthar Ali Keerio \\ Associate Professor, Department of Civil Engineering, Quaid-e-Awam University of \\ Engineering Science \& Technology Larkana campus, Sindh, Pakistan. \\ Naraindas Bheel \\ Ph.D Scholar, Department of Civil and Environmental Engineering, Universiti Teknologi \\ PETRONAS, Bandar Seri Iskandar, Tronoh, Perak, 31750, Malaysia
}

\begin{abstract}
Concrete is frequently utilized infra-structural construction material all over the world. Cement is the main part of the concrete, during its manufacturing emission of gases such as carbon dioxide (CO2) from cement factories create greenhouse effect. In these days various natural pozzolanic materials are used as partial replacement of cement to enhance strength and durability and to reduction in consumption of cement consequently reduction in carbon dioxide (CO2) emission. The aim of this research is to investigate the effect of groundnut shell ash as a cement replacement material on workability and compressive strength of concrete. One mix of ordinary concrete and five mixes of modified concrete were prepared, where cement is replaced by groundnut shell ash from $3 \%$ to $15 \%$ by weight of cement, with $3 \%$ increment with $1: 2: 4$ binding ratio mixed with 0.5 water/cement ratio. The workability and compressive strength of concrete was investigated. The obtained outcomes demonstrated that, groundnut shell ash as a cement replacement material have significant effect on compressive strength of concrete.
\end{abstract}

\section{Keywords}

Compressive Strength of Concrete, Workability, Partial replacement of cement

\section{INTRODUCTION}

Concrete is frequently utilized infra-structural construction material all over the world. The main mix proportions of concrete are \{cement, fine aggregate (FA), course aggregate (CA) and water [1], [2]. Many researchers have conducted investigations on mechanical properties (flexural strength, Tensile strength, compressive strength, flexural strength, density, etc) by using different cement contents, various types of aggregates with water/binder ratios [3], [4], [5], [6]. Cement is binding agent contain lime, silica, alumina and iron oxide. By its production, consumption and need we did not reach over its requirements [7], [8], [9], [10], [11]. Cement is the main part of the concrete, during its manufacturing emission of gases such as carbon dioxide (CO2) from cement factories create greenhouse effect [12]. In these days various natural pozzolanic materials are partially replaced in cement to enhance strength, stability and durability [13]. The usage of partially replacement cementitious materials (RCMs) with cement which decreasing the pollution impact and saving environment from the factories, mills and the industries. RCMs materials are Palm-Kennel Shell (PKS), Saw Dust Ash (SDA), Corn Cob Ash (CCA), Millet Husk Ash (MHA), Rise Husk Ash (RHA), Sugarcane Bagasse Ash (SCBA), Groundnut Shell Ash (GSA), etc [14], [15], [16], [17]. These replacements can be improved the workability, durability, early and long term strength and economy based in the blended cement concrete [18]. In this experimental study work the benefits of ground-nut shell ash (GSA) as partially substitution of cement (OPC) in concrete. Groundnut is usually agriculture 
product of Nigeria. Its waste is widely collected which contains $20 \%$ to $24 \%$ shell of harvested groundnut, even the ratio changes by variety. Around 58 tons of groundnut shell yield is generated per year throughout the world [19]. Globally China is known as the major groundnut producer country around 14.30 million metric tons of groundnut is produced by China [20]. In Pakistan groundnut is cultivated in Punjab, Khyber Pakhtunkhwa (KPK) and Sindh provinces while in Baluchistan no groundnut is cultivated. The Punjab produce $85 \%$, Khyber Pakhtunkhwa $10 \%$, and Sindh $5 \%$ respectively. About 102400 hectares an area in Pakistan was cultivated through this overall production about 114700 tons with an average of yield $1121 \mathrm{~kg} /$ hectare. Around 68 to $72 \%$ of groundnut manufacture of Pakistan is found in rain fed (barani) region in Chakwal, Attock and Rawalpindi the northern districts province of Punjab [21]. The analysis of chemical composition of groundnut shell ash is taken to assure the properties whether cementing or pozzolanic and use as partial replacement of GSA in OPC [22]. This agriculture waste of GSA is partially replaced for cement in concrete could lessen the construction cost and hazards of waste disposal [23]. However, the purpose of this experimental work to determine the slump test and compressive strength test with accumulation of GSA as cementitious components in concrete.

\section{MATERIALS AND METHODS}

\subsection{Materials}

Local available OPC cement was used in this research. However, the ground nut shell was collected from Larkana, Pakistan and then it was burnt at uncontrolled temperature under the atmosphere to convert into ash for four hours. After that the ash was left for 24 hours for cooling and then it was sieved from \#200 sieve. After sieving ash, it was used as partial replacement of cement in concrete as $0 \% 3 \%, 6 \%, 9 \% 12 \%$ and $15 \%$ by the weight of cement. Moreover, the hill sand was passed from sieve size $4.75 \mathrm{~mm}$ and coarse aggregate was passed from sieve size $20 \mathrm{~mm}$ in this study. Furthermore, the tap water was served in the mixing and curing of research work.

\subsection{Methods}

In this research mechanical properties of concrete such as compressive strength and workability were conducted blended with $0 \%, 3 \%, 6 \%, 9 \%, 12 \%$ and $15 \%$ of GSA as cement substitute ingredient in concrete with 1:2:4 binding ratio mixed with 0.5 water/cement ratio. However, Slump test was conducted for workability as per code specification of (BS-1881-102-1983). Moreover, for each batch of compressive strength, 5 cubes were made at the curing age of 3 and 28 days as per code specification of (BS 12390-3-2009) while the size of cube was $100 \mathrm{~mm} \times 100 \mathrm{~mm} \times 100 \mathrm{~mm}$ used for testing.

\section{RESULTS AND DISCUSSIONS}

\subsection{Workability of Groundnut Shell Ash concrete}

Slump value of Groundnut shell ash concrete is shown in Figure 1.

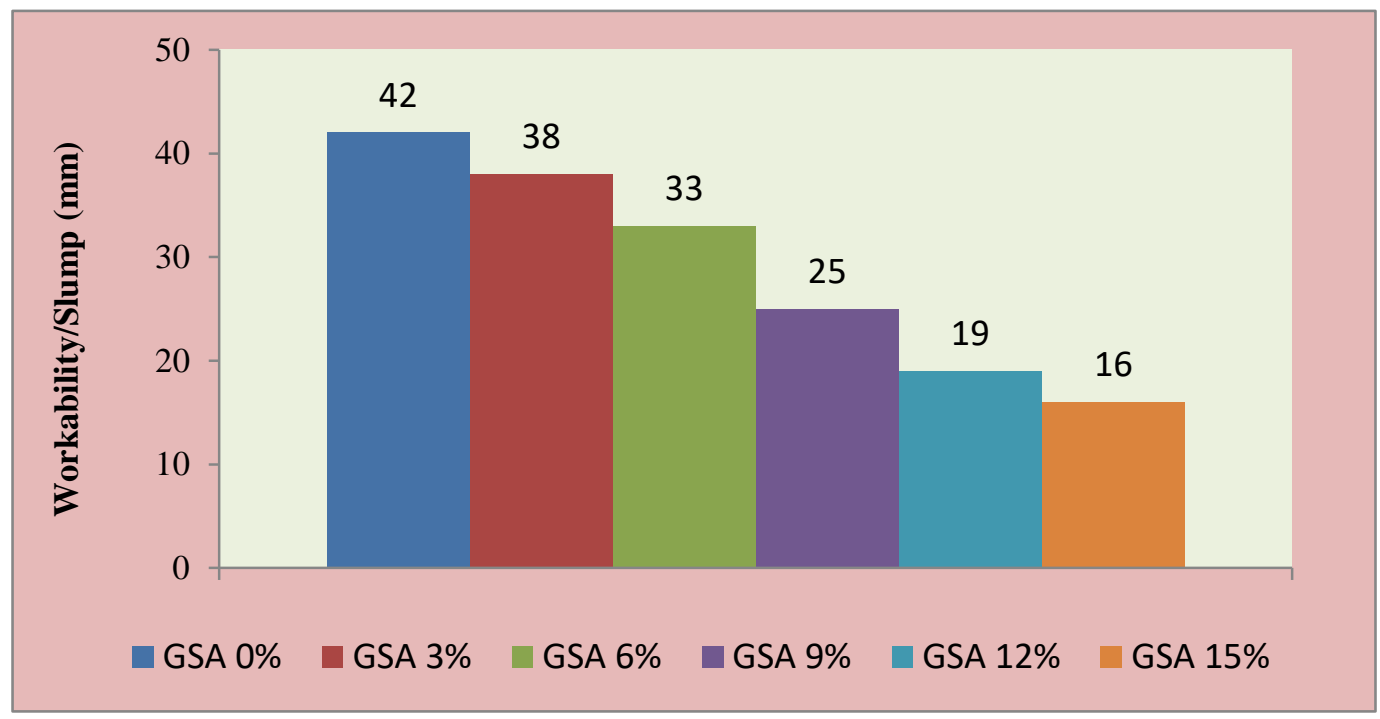

Figure 1: Slump Test of GSA Concrete 
It can be observed in above Figure 1 that with the inclusion of Groundnut shell ash, Slump value is decreasing with the comparison of ordinary Portland cement concrete.

\subsection{Compressive Strength of Groundnut shell ash concrete}

Compressive strength of Groundnut shell ash concrete is shown in Figure 2.

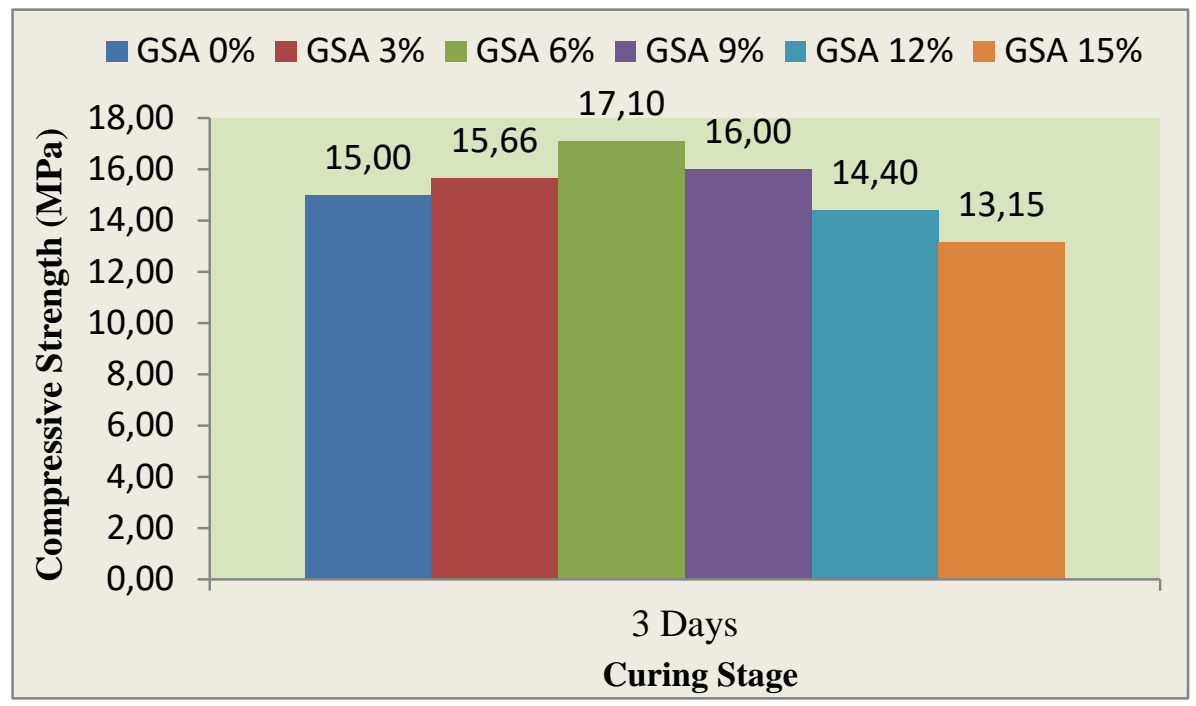

Figure 2 : Compressive strength of Groundnut shell ash

In the above results shown in Figure 2, it is discussed that the compressive strength of the groundnut shell ah is increased up to $6 \%$ in comparison of control mix. The Additional substitution of binding material with ash of groundnut shell beyond $6 \%$, the compressive strength is decreased than that of normal mix. The highest compressive strength $17.10 \mathrm{MPa}$ is accomplished at $6 \%$ substitution of cement with ash of groundnut shell which is $14 \%$ more than that of ordinary Portland cement concrete after 3 days.

\subsection{Compressive Strength of Groundnut shell ash concrete}

Compressive strength of Groundnut shell ash concrete is shown in Figure 3.

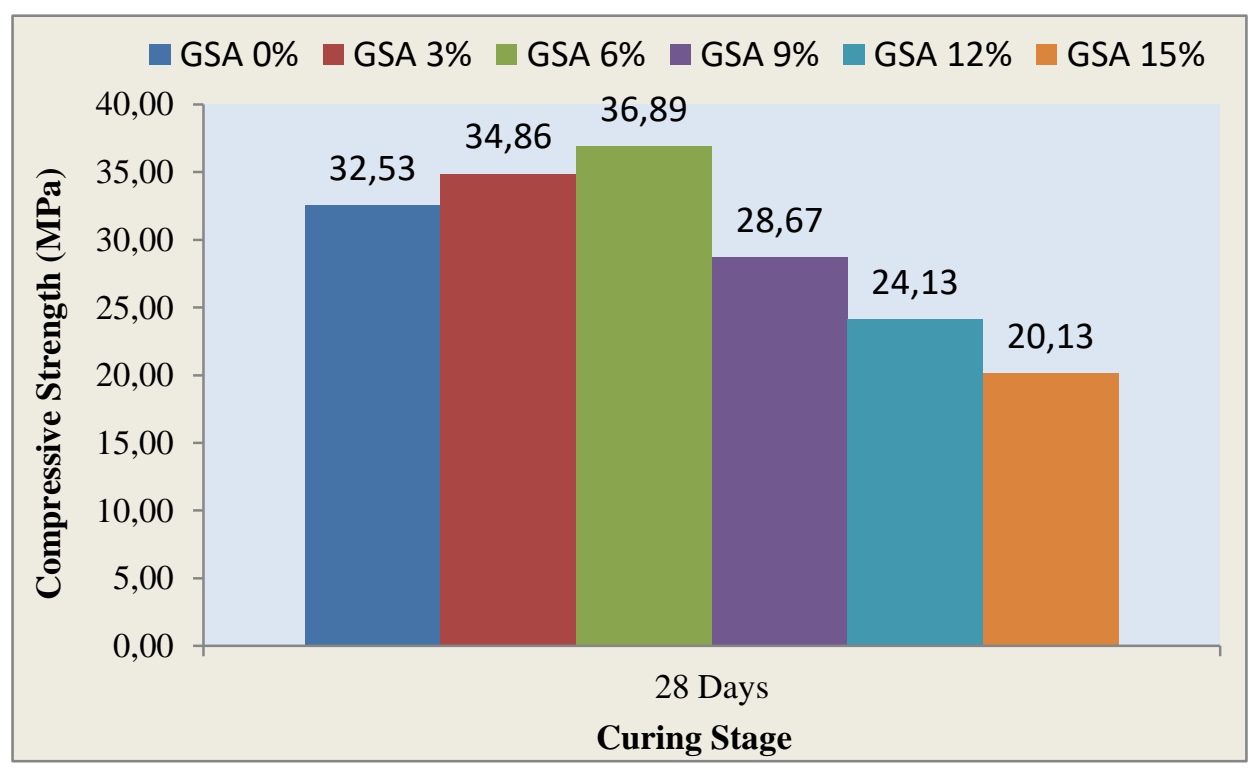

Figure 3: Compressive strength of Groundnut shell ash

In the above results shown in Figure 3, it is discussed that the compressive strength of the groundnut shell ash is increased up to $6 \%$ in comparison of control mix. The Additional substitution of binding material with ash of groundnut shell after $6 \%$, the compressive strength is decreased than that of normal mix. The highest compressive strength $36.89 \mathrm{MPa}$ is accomplished at $6 \%$ substitution of 
cement with ash of groundnut shell which is $13.41 \%$ more than that of ordinary Portland cement concrete.

\section{CONCLUSION}

On the research based it can be summarized that:

a) The workability of slump test indicates, with the substitution of groundnut shell ash it is decreased as compared with the normal mix.

b) Compressive strength of the groundnut shell ash concrete is increased up to $6 \%$ in comparison of control mix. The Additional substitution of binding material with ash of groundnut shell beyond $6 \%$, the compressive strength is decreased than that of normal mix.

c) The highest compressive strength $36.89 \mathrm{MPa}$ is accomplished at $6 \%$ substitution of cement with ash of groundnut shell which is $13.41 \%$ more than that of ordinary Portland cement at 28 days.

On the above observation, it can be summarized that $6 \%$ replacement of cement with groundnut ash is optimum for construction industry.

\section{References}

[1] A. Ghayoor Khan, B. Khan, E. Abdul Ghayoor khan, and B. khan, "Effect of Partial Replacement of Cement by Mixture of Glass Powder and Silica Fume Upon Concrete Strength Effect of Partial Replacement of Cement by Mixture of Glass Powder and Silica Fume Upon Concrete Strength Effect of Partial Replacement of Cement by Mixture of Glass Powder and Silica Fume Upon Concrete Strength," Kam-bohwell Publisher Enterprises, 2017.

[2] S. Chandra and L. Berntsson, Lightweight Aggregate Concrete, 1st ed. New York: Noyes Publications, 2002.

[3] G. Girish and R. M. Rao, "A Step towards Mix Proportioning Guidelines for Pervious Concrete," Int. J. Earth Sci. Eng., vol. 4, no. 6, pp. 768-771, 2011.

[4] J. T. Kevern, V. R. Schaefer, and K. Wang, "The effect of curing regime on pervious concrete abrasion resistance," J. Test. Eval., vol. 37, no. 4, pp. 337-342, Jul. 2009, doi: 10.1520/jte101761.

[5] C. Lian and Y. Zhuge, "Optimum mix design of enhanced permeable concrete - An experimental investigation," Constr. Build. Mater., vol. 24, no. 12, pp. 2664-2671, 2010, doi: 10.1016/j.conbuildmat.2010.04.057.

[6] R. Shankar and N.Palanka, "A Study on Porous Concrete Mixes for Rigid Pavements," Indian Highw., vol. 43, pp. 37-41, 2015.

[7] D. D. Arivu and T. Selvan, "Durability Studies on Concrete by using Groundnut Shell Ash as Mineral Admixture," IJIRST-International J. Innov. Res. Sci. Technol., vol. 3, no. 10, pp. 168$172,2017$.

[8] N. Bheel, R. A. Abbasi, S. Sohu, S. A. Abbasi, A. W. Abro, and Z. H. Shaikh, "Effect of Tile Powder Used as a Cementitious Material on the Mechanical Properties of Concrete," Eng. Technol. Appl. Sci. Res., vol. 9, no. 5, pp. 4596-4599, 2019.

[9] A. A. Dayo, A. K. Hindu, A. Raja, and N. Das Bheel, "Use of Sugarcane Bagasse Ash as a Fine Aggregate in Cement Concrete," Eng. Sci. Technol. Int. Res. J., vol. 3, no. 3, pp. 8-11, 2019.

[10] N. Bheel, M. A. Jokhio, J. A. Abbasi, H. B. Lashari, M. I. Qureshi, and A. S. Qureshi, "Rice Husk Ash and Fly Ash Effects on the Mechanical Properties of Concrete," Eng. Technol. Appl. Sci. Res., vol. 10, no. 2, pp. 5402-5405, Apr. 2020, doi: 10.48084/etasr.3363.

[11] N. Bheel, S. A. Abbasi, S. L. Meghwar, and F. A. Shaikh, "Effect of Human Hair as Fibers in Cement Concrete," Int. Conf. Sustain. Dev. Civ. Eng. 23th -25th, Novemb. 2017, vol. 1, pp. 67-72, 2017.

[12] M. S. Imbabi, C. Carrigan, and S. McKenna, "Trends and developments in green cement and concrete technology," International Journal of Sustainable Built Environment, vol. 1, no. 2. Elsevier B.V., pp. 194-216, Dec. 2012, doi: 10.1016/j.jisbe.2013.05.001.

[13] N. V. Lakshmi and P. S. Sagar, "Study on Partial Replacement of Groundnut Shell Ash with Cement," J. Concr. Res. Lett., vol. 8, no. 3, pp. 84-90, 2017, doi: https://doi.org/10.20528/cjcrl.2017.03.002.

[14] G. M. . Islam, M. M. Islam, A. Akhter, and M. S. Islam, "Green Construction MaterialsBangladesh Perspective," in Proceedings of the International Conference on Mechanical Engineering and Renewable Energy 2011, (ICMERE2011) 22-24 December 2011, 2011.

[15] N. Bheel, K. A. Kalhoro, T. A. Memon, Z. U. Z. Lashari, M. A. Soomro, and U. A. Memon, "Use of Marble Powder and Tile Powder as Cementitious Materials in Concrete," Eng. Technol. Appl. Sci. Res., vol. 10, no. 2, pp. 5448-5451, Apr. 2020, doi: 10.5281/ZENODO.3748340. 
[16] N. Bheel and A. Adesina, "Influence of Binary Blend of Corn Cob Ash and Glass Powder as Partial Replacement of Cement in Concrete," Silicon, pp. 1-8, Jun. 2020, doi: 10.1007/s12633020-00557-4.

[17] N. Bheel, F. A. Memon, and S. L. Meghwar, "Study of Fresh and Hardened Properties of Concrete Using Cement with Modified Blend of Millet Husk Ash as Secondary Cementitious Material," Silicon, pp. 1-12, 2020, doi: 10.1007/s12633-020-00794-7.

[18] R. J. Detwiler, J. I. Bhatty, and S. Battacharja, Supplementary Cementing Materials For Use In Blended Cements. Skokie, Illinois: Research and Development Bulletin, 1996.

[19] N. Y, Rice: Post Harvest Technology. Tokyo, 1999.

[20] M. Shahbandeh, "Peanut: leading producers worldwide 2018," Statista, 2020. .

[21] J. Akhtar, S. Mehdi, K. Mahmood, and M. Sarfraz, "Effect of Deep Tillage Practices on Moisture Preservation and Yield of Groundnut under Rainfed Conditions," J. Agric. Soc. Sci., vol. 1, no. 2, pp. 98-101, 2005.

[22] R. Dineshkumar and H. H. Arshad, "Performance of concrete properties by groundnut shell ash as a partial replacement of cement with sisal fiber," Int. J. Civ. Eng., 2017.

[23] N. V. Lakshmi and P. S. Sagar, "Experimental Study on Determination of Compressive Strength of Ground Nut Shell Ash on Partial Replacement with Cement," Int. J. Res. Appl. Sci. Eng. Technol., vol. 5, no. 8, pp. 1492-1496, Aug. 2017, doi: 10.22214/ijraset.2017.8211. 